\title{
The Use of Online Slang for Independent Learning in English Vocabulary
}

\author{
Sasha Ambarsari* \\ Postgraduate English Department \\ Universitas Mataram \\ Mataram, Indonesia \\ sashaambarsari29@gmail.com
}

\author{
Amrullah Amrullah \\ Postgraduate English Department \\ Universitas Mataram \\ Mataram Indonesia
}

\author{
Nawawi Nawawi \\ Postgraduate English Department \\ Universitas Mataram \\ Mataram, Indonesia
}

\begin{abstract}
The study entitled The Use of Online Slang for Independent Learning in English Vocabulary. It aims to analyze the types of slang words, the media that influence the learners to use slang words. This study also investigates the reason why the learners used slang words. This study used Elisa Mattielo (2008) theory to analyze the types of slang words used by learners. The data were collected from questionnaires and interviews. The finding shows that there are two types of slang words which were commonly used by learners; they are Informality and Debasement and Vulgarity and Obscenity. The Informality and Debasement were commonly used by learners to express informal words with their close friends. The Vulgarity and Obscenity were usually used to express their anger to their friends such as fool, bitch, fuck, damn, motherfucker, holly shit, and goddamn. Further, it was found that the internet, social media, movies, and songs were the media and the sources which the learners can access to learn slang words through independent learning. The learners used slang words to be humorous, creative, attractive, joy, and even just to follow what friends do. In addition, this can add the learners' vocabulary of English words.
\end{abstract}

Keywords - online slang, independent learning, English vocabulary.

\section{INTRODUCTION}

Nowadays, teaching style changes from traditional to modern teaching. In traditional teaching, the interaction is dominated by the teacher because the materials are from the teacher, while the students should repeat and memorize the materials. It makes the students less in critical thinking, problem-solving and making skills. While in modern teaching, the interaction is dominated by the students because they seek the materials by themselves while the topics are developed by the teacher. So, students can explore new things that make the students more productive and collaborative in class. Basically, traditional and modern teaching are effectively used in teaching classes.

Thus, we move out from the traditional method to modern method called industrial revolution 4.0. At this time, it usually refers to the digital era which is present everything on online media. In the 4.0 era, modern teaching can develop the learners' knowledge of English words by using online materials. The learners can find many words of English that can be formal and informal such as in the academic context or daily life. To communicate with friends, learners usually use slang words to make a secret meaning. Adolescents like to use slang rather than formal language because it shows solidarity with group members. Slang commonly used in spoken languages by a particular group of people, adults, criminals, soldiers, etc. as an informal word and expressions [1].

The slang words present in online materials or on the internet, such as YouTube, movies, songs, social media, and so forth. The learners can access online slang freely on the internet. It gives a lot of types of slang words. But, in the school curriculum, the slang words do not exist because it is an impolite word to use in an academic context. Therefore, learners can study slang words at home and sharing with their friends. It refers to independent learning, which means that the learner adds the knowledge of slang words by his or her self with efforts, and it can develop their ability in the study. Independent learning known as self-directed which the learning activity organized and completed by learner and teachers may act as guides [2]. The learners also can take responsibility for their work by plans the time, make a note, get the information, and remember the important point and feel confident. Ebata mentioned that developing independent learning is essential in generating successful learners [3]. Therefore, the possibilities source of independent learning is online materials because it easier to access and can get more information about the online slang words. It can be a good way to develop their vocabulary of English words.

Furthermore, the knowledge of vocabulary is a key to master English, because the learners need enough vocabulary to know the structures and functions of English. Vocabulary is one of the language components evaluated in tests [4]. It refers to the use of words in the language that are usually found in the dictionary. However, almost all the slang words do not exist in the dictionary and thus, learners are able to learn slang words through independent learning. This study was intended to find out the types of slang words that are commonly used by learners, the factors or media that influence learners to use slang words, and also the reasons why they use slang words.

\section{METHOD}

The study uses the descriptive qualitative method. The subject of the study is the students of MA Negeri 2 Mataram in class XI IPS Unggulan, which consists of 38 students (18 males and 20 females). The questionnaire and interview were used to collect the data needed. There are ten items of questionnaire which the students were required to answer. After that, the students were interviewed to investigate the type of slang words they 
use, the media that influence them to use slang, and the reason why the students want to use slang words. The data were first classified based on Elisa Matiello's] theory to find the type of slang words. Next, the data gotten from questionnaires and interviews were analyzed to get the answers to the purpose of the study [5].

\section{RESUlTS AND DISCUSSION}

This study found that there were 35 slang words used by the learners. Based on the classification for the five types of slang words: Group and Subject Restriction, Secrecy and Privacy, Informality and Debasement, Vulgarity and Obscenity, and Time-restriction, Ephemerality, and Localism, it was found that those 35 slang words were in the third and fourth types only (see table 1)

The third type is informality and debasement. It usually expresses the standard words into the informal with a close friend in a group. This type usually use by the speaker to break the neutral standard language into a low speech ${ }^{[6]}$. The study shows that the informality and debasement type is commonly used by learners. There are 28 slang words found in this type such as FYI (For Your Information), LOL (Laugh Out Loud) means extremely funny, OMG (Oh My God, Oh My Goodness, or Oh My Ghost), Yep/Yup means Yes, Gonna means Going to, Wanna means Want to, Gotta means Got to, Kinda means Kind of, ASAP (As Soon As Possible), BRB (Be Right Back), Fella means someone, Guys, Dude, Bro, Cool, Sist, Impressive, BTW (By The Way), KIT (Keep In Touch), P.S (Postscript), P.P.S (Post-post-script), Okey-dokey, GG (Good Game), Epic means extremely awesome, Lit means amazing, Savage means cruel, and YOLO (You Only Live Once).

Further, the fourth type is Vulgarity and Obscenity which means that the speaker used swear, dirty, and taboo slang to express their anger, insult, and peevish to their friends. This study shows 7 slang words commonly used by the learner when they feel angry with their friends such as fool, bitch, fuck (what the fuck or as fuck), damn, motherfucker, holly-shit, and goddamn.

TABLE I. TYPES OF SLANG WORDS

\begin{tabular}{|l|l|c|}
\hline No. & \multicolumn{1}{|c|}{ Types of Slang Words } & Frequency \\
\hline 1. & Group and Subject Restriction & - \\
\hline 2. & Secrecy and Privacy & - \\
\hline 3. & Informality and Debasement & 28 \\
\hline 4. & Vulgarity and Obscenity & 7 \\
\hline 5. & $\begin{array}{l}\text { Time-restriction, Ephemerality, and } \\
\text { Localism, Total }\end{array}$ & - \\
\hline \multicolumn{2}{|c|}{. } \\
\hline
\end{tabular}

Based on these findings, it can be said that the types of slang words that were commonly used by learners are informality \& debasement and vulgarity \& obscenity.

\section{A. The Media Influencing the Learner in Using Slang Words}

The study use questionnaire to provide the data and interview to investigate what media influence the learners use the slang words. The learner often heard the slang words, but firstly they did not know if those words are the slang words. Then, They applied independent learning to find out the slang words and seek it from the internet, social media (Twitter, YouTube, and Instagram), movies, and songs. Their friends sometimes used slang words when they want to make a caption of the picture on their social media. Then they followed some public figures which often used slang words on social media. The learner also likes watching English movies and listening to English songs to increase their vocabulary of slang words. The learners inform that they can find many slang words in movies and songs such as the informality and vulgarity types of slang words. The online slang is very helpful for the learners because they enjoy learning the slang words independently from the internet and find new words easily to develop their vocabulary in English.

Therefore, most media that influence learners using slang words are from the internet, social media, movies, and songs. The learners prefer to access social media, watch movies, and listen to songs to explore new words, especially on slang words.

TABLE II. QUESTIONS

\begin{tabular}{|l|l|l|l|l|l|}
\hline No. & Questions & $\mathrm{Nv}$ & $\mathrm{Sl}$ & $\mathrm{Sm}$ & $\mathrm{Fq}$ \\
\hline 1. & Do you know slang word? & 2 & 3 & 5 & 28 \\
\hline 2. & Do you use the slang words? & 2 & 3 & 10 & 23 \\
\hline 3. & How often do you use slang words? & 3 & 8 & 15 & 12 \\
\hline 4. & Do you speak slang words at school? & 2 & 3 & 5 & 28 \\
\hline 5. & Do you speak slang words at home? & 3 & 7 & 13 & 15 \\
\hline 6. & $\begin{array}{l}\text { Do you speak slang words with your } \\
\text { friends? }\end{array}$ & 2 & 3 & 4 & 29 \\
\hline 7. & $\begin{array}{l}\text { Do you know slang from the } \\
\text { internet? }\end{array}$ & 2 & 2 & 5 & 29 \\
\hline 8. & $\begin{array}{l}\text { Is social media influence you to used } \\
\text { slang words? }\end{array}$ & 1 & 2 & 5 & 30 \\
\hline 9. & $\begin{array}{l}\text { Are movies and songs make you } \\
\text { know slang words? }\end{array}$ & 0 & 3 & 4 & 31 \\
\hline 10. & $\begin{array}{l}\text { Do you know the popular slang } \\
\text { words? }\end{array}$ & 2 & 2 & 6 & 28 \\
\hline
\end{tabular}

Note. $\mathrm{Nv}=$ Never, $\mathrm{Sl}=$ Seldom, $\mathrm{Sm}=$ Sometimes, $\mathrm{Fq}=$ Frequently

The table above shows that the learners mostly know the slang word because there are 28 students answer 'frequently' in the questionnaires. Then, some students answer 'frequently' and 'sometimes' in the use of slang words at schools and at home. Most of the students used slang words with their friends (frequently 30). Then, the role of the internet (29), social media (30), movies, and songs (31) influence the learner to speak with slang words and familiar slang words.

\section{B. The Reason Why Students Used Slang Words}

Most of the learners gave the same reason why they used slang words when talking with their friends. They wanted to be humorous, creative, attractive, joy, even because the other friends used it. In this case, the learners' vocabulary of English words can increase. Slang can express the ideas, feeling, attitude, and how people can infer what you mean ${ }^{[7]}$. They can say something uniquely and more easily with slang words. Adolescents use slang words to shorter the sentences and easy to understand [6].

The learners can express their anger by using slang words. Slang words allow to express anger [6]. They want to make the other friends confused when they talk with their group. It can show the identity and solidarity of a 
group [7]. Then, the learners used slang words for fun with their friends and to take the attention of other people.

\section{CONCLUSION}

From the five types of the slang word that presented by Mattielo (2008), there are only two types of slang words used by learners. Firstly, informality and debasement. This type is commonly used by learners to express informal words with their close friends such as FYI (For Your Information), LOL (Laugh Out Loud) means extremely funny, OMG (Oh My God, Oh My Goodness, or Oh My Ghost), Yep/Yup means Yes, Gonna means Going to, Wanna means Want to, Gotta means Got to, Kinda means Kind of, ASAP (As Soon As Possible), BRB (Be Right Back), Fella means someone, Guys, Dude, Bro, Cool, Sist, Impressive, BTW (By The Way), KIT (Keep In Touch), P.S (Postscript), P.P.S (Post-post-script), Okey-dokey, GG (Good Game), Epic means extremely awesome, Lit means amazing, Savage means cruel, and YOLO (You Only Live Once). Secondly, vulgarity and obscenity. It usually used to express their anger with their friends such as fool, bitch, fuck (what the fuck or as fuck), damn, motherfucker, hollyshit, and goddamn.

Further, the media which influenced learners in using slang words are the internet, social media, movies, and songs. The learners prefer to access social media, watch movies, and listen to songs to explore new words, especially on slang words. They sometimes used slang words at schools and daily life with their friends. They used slang words to be humorous, creative, attractive, joy, even because the other friends used them.

\section{REFERENCES}

[1] A. S. Hornby, Advanced Learner's Dictionary of Current English 7th Ed. Walton Street: Oxford University Press, 2005.

[2] B. Meyer, N. Haywood, D. Sachdev, and S. Faraday, "What is independent learning and what are the benefits for students," Dep. Child. Sch. Fam. Res. Rep., vol. 51, 2008.

[3] M. Ebata, "Awakening Opportunity: Three Elements to Foster Learners' Autonomy.," Online Submiss., 2010.

[4] N. Schmitt, "The relationship between TOEFL vocabulary items and meaning, association, collocation and word-class knowledge," Lang. Test., vol. 16, no. 2, pp. 189-216, 1999.

[5] E. Mattiello, An introduction to English slang: A description of its morphology, semantics and sociology, vol. 2. PolimetricaInternational Scientific Publisher, 2008.

[6] P. L. Gerber, Lessons in Language. Wadsworth Publishing Company, 1968.

[7] B. Spolsky, Sociolinguistics, vol. 1. Oxford university press, 1998. 